\title{
Improvement of procedures for the selection of optimal taxation scheme of agricultural organizations of Krasnodar Territory
}

\author{
Yuri Sigidov \\ Kuban State Agrarian University, \\ Department of Accounting Theory \\ Krasnodar, Russia \\ $\underline{\text { tbu_kuban@mail.ru }}$
}

\author{
Vadim Bashkatov \\ Kuban State Agrarian University \\ Department of Accounting Theory \\ Krasnodar, Russia \\ vadim.bashkatov@mail.ru
}

\begin{abstract}
This article is devoted to improving the procedure for choosing the optimal taxation scheme. The analysis of the current condition of agricultural organizations in the field of taxation was carried out in the years 2012-2016 for the totality of agricultural organizations of Krasnodar Territory. The structure of taxation schemes used by agricultural organizations of the Krasnodar Territory is given. An algorithm for analyzing the possibility of switching to special taxation regimes by agricultural organizations is given. On the basis of the algorithm, we developed the form of a checklist for compliance with the conditions for the transition to special taxation schemes, and also tested the compliance with the conditions of application of special taxation regimes by the example of the organization being studied. The methodology for calculating the optimal taxation scheme is developed.
\end{abstract}

Keywords - taxation scheme, tax burden, agricultural organization, management analysis, Krasnodar Territory

\section{INTRODUCTION}

Currently, agricultural organizations face the problem of choosing the optimal tax regime. This process is quite costly and time consuming, as it requires complex economic and accounting calculations, which in the future will serve as the basis for making managerial decisions. Tax analysis is an important component of corporate tax management. Information formed in the course of tax analysis, allows you to make sound management decisions in the field of taxation with minimal tax risks. The foregoing causes the relevance of the research topic.

The aim of the study is to substantiate theoretical provisions and develop practical recommendations for improving the methods for selecting the optimal taxation regime in agricultural organizations.

The interaction of tax analysis with other elements of the accounting and tax system was studied by such scientists as A.A. Zhidikin, E.Yu. Zolochevskaya, A.P. Ivanov, V.B. Ivashkevich, V.G. Kryuchkov, N.T. Labyntsev, M.Yu. Medvedev, and others.

Theoretical aspects of the methodology for conducting tax analysis were investigated by A.P. Aletkin, A.M. Vasiliev,
E.V. Egorova, V.G. Kogdenko, Z.I. Kruglyak, L.V. Popova, E.S. Smirnov, E.V. Chipurenko et al.

A significant contribution to the development of methods of tax optimization and its tools was made by A.V. Bryzgalin, V.R. Bernik, A.N. Golovkin, A.P. Lushchikova, E.I. Lebedev.

The studies in the field of tax analysis, tax planning, forecasting, made a significant contribution to the development of the problems under consideration, but a number of issues (in particular, the methods for selecting the optimal tax regime) led to the direction of the research, its purpose and objectives.

\section{Materials AND MethodS (Model)}

The methodological and theoretical basis of the study was the work of domestic and foreign economists in the field of tax and management accounting, tax management, tax analysis, legislative and regulatory acts of the Russian Federation and the Krasnodar Territory.

To achieve the goal and objectives, the following methods and methods were used: monographic, economic-statistical, graphical, observation, generalization, systematization, analysis and synthesis, modeling, etc.

The information base of the research was data of the Federal State Statistics Service of the Krasnodar Territory, the Federal Tax Service of the Russian Federation, accounting registers and reports of agricultural organizations of the Krasnodar Territory.

\section{RESULTS AND DISCUSSION}

The analysis of the current condition of agricultural organizations in the field of taxation was carried out in the years 2012-2016 for the totality of agricultural organizations of Krasnodar Krai.

Figure 1 shows the dynamics of accrued and paid taxes and fees, contributions to non-budgetary funds for the years 2012-2016. 
The amount of accrued and paid taxes and fees for the years 2012 - 2016 has the tendency to grow. Thus, in 2016 the amount of accrued tax payments amounted to RUB $18,862,469$ thousand, which is $63.6 \%$ more than in 2012 . The amount of taxes and fees transferred to the budget increased in the reporting year compared with the base year to RUB 7724231 thousand $(71.1 \%)$.

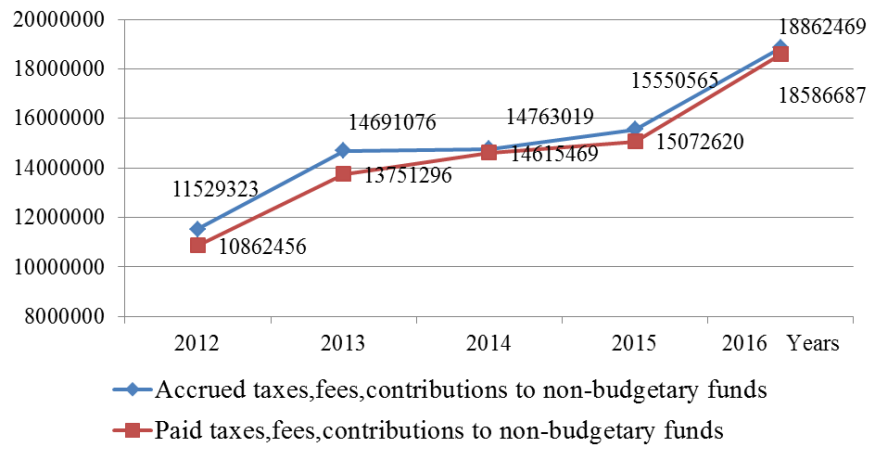

Fig. 1. The dynamics of accrued and paid taxes, fees, contributions to nonbudgetary funds, RUB th.

Figure 2 shows the structure of tax regimes applied by agricultural organizations of Krasnodar Krai.

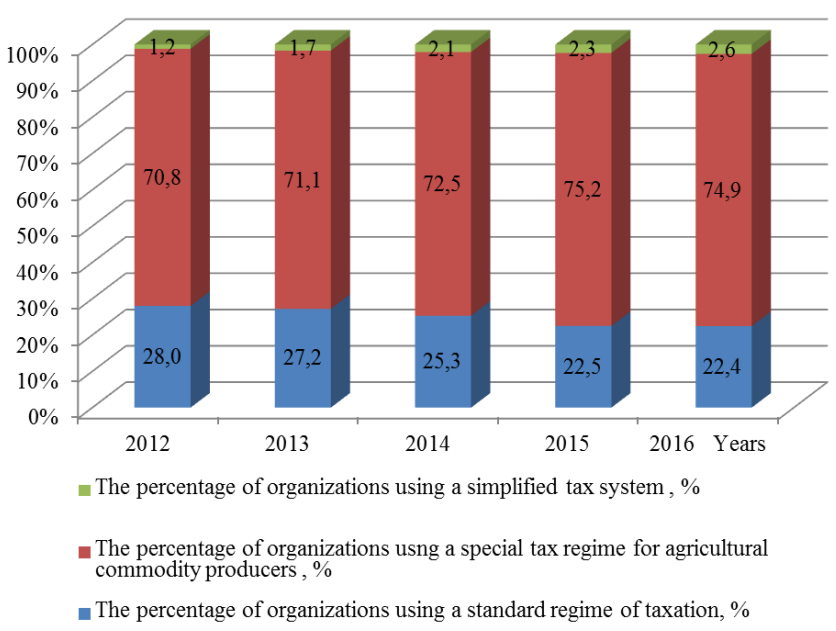

Fig. 2. The distribution of agricultural organizations of Krasnodar Krai to applied tax regimes in percentage correlation

The analysis of statistical data shows that the majority of agricultural organizations of Krasnodar Territory uses the special tax regime for agricultural commodity producers (in 2016 the percentage of such organizations amounted to 74.9\%). However, some organizations (often large manufacturing complexes which is inherent in manufacture diversification) remain on a standard tax regime, the percentage of such organizations during the reporting period is about $25 \%$. The percentage of organizations applying the simplified tax system is insignificant (in 2016 it was only $2.6 \%$ ), this is related to the fact that this tax regime can be applied only by small agricultural commodity producers.
The steps of selecting the optimal taxation scheme are as follows:

1. Check of eligibility for transition to a particular tax regime. Conditions for transition to UAT are specified in Art. 346.1 of the Tax Code of the Russian Federation and to STS in Art. 346.12 of the Tax Code of the Russian Federation.

2. Determination of the tax field for different taxation schemes and identification of their advantages and disadvantages.

3. Calculation of tax expenditures for alternative taxation regimes.

4. Comparison of the tax burden for different schemes.

5. Making management decisions on the choice of the optimal taxation scheme.

Organizations transfer to the payment of the unified agricultural tax under the following conditions:

- the organization (individual entrepreneur) should be an agricultural producer (i.e. the proportion of income from sales of products manufactured by the organization, including primary processing products produced from agricultural raw materials of its own production, must be at least $70 \%$ of total income from sales of goods (works, services));

- organizations which can transfer to the payment of the unified agricultural tax also include Russian town- and settlement-forming fish farms, if the number of employees together with cohabitating family members makes up at least half of the population of the locality concerned.

Conditions for transition from the standard taxation scheme to the simplified system are specified in the Tax Code of the Russian Federation:

- an organization has the right to transfer to the simplified tax system if its total income for nine months of the year in which the notice on the transition to the simplified tax system was filed did not exceed 45 million rubles. In this case the amount of income is subject to indexation;

- the average number of employees of the organization for the tax (reporting) period should not exceed 100 people;

- organizations, in which the share of direct participation of other organizations is more than $25 \%$, do not have the right to transfer;

- organizations that have a residual value of fixed assets, as defined in accordance with the accounting procedure, in excess of 100 million rubles also lose the right to transfer to the simplified tax system. 


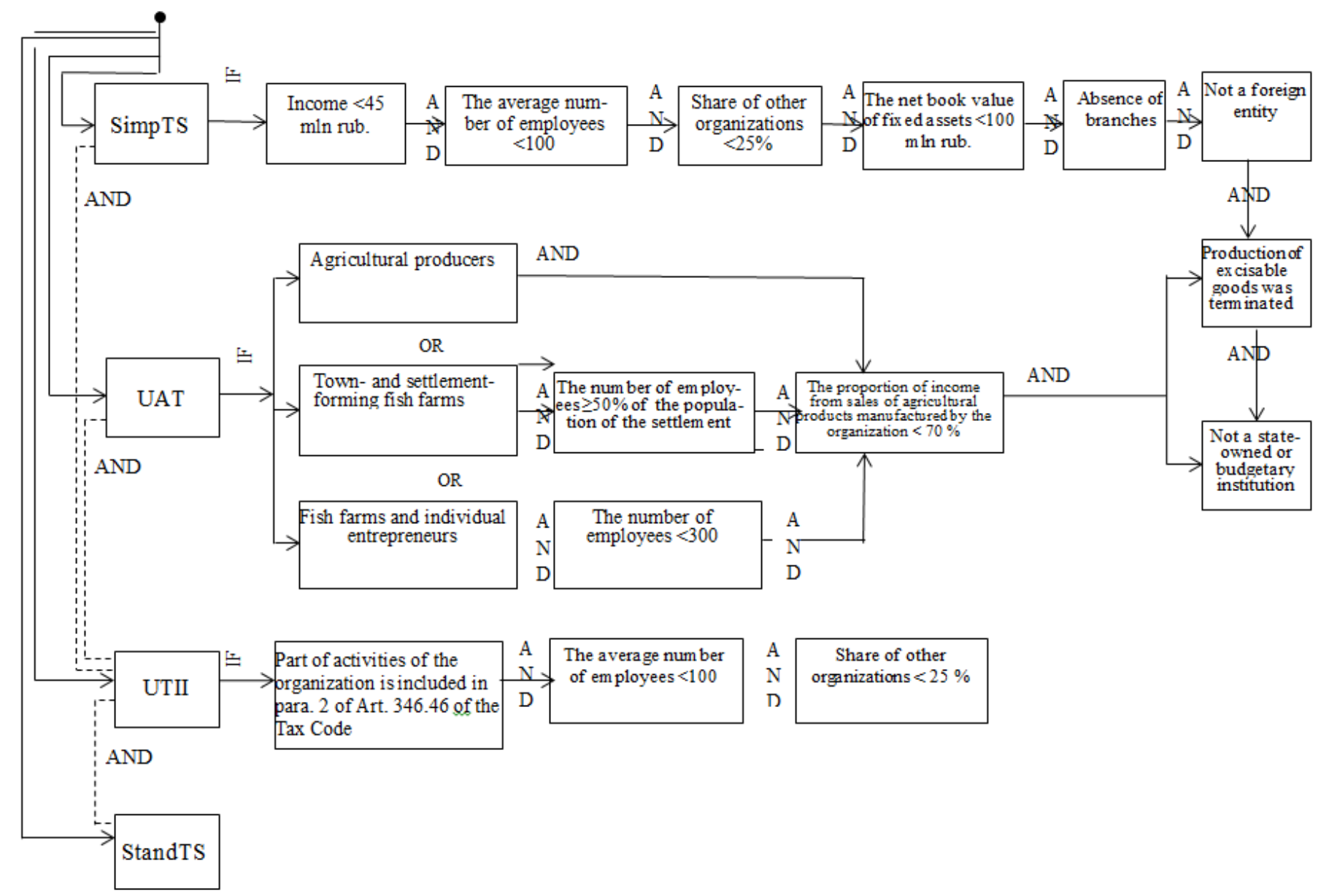

Fig. 3 The algorithm of analyzes of eligibility for transition to the special tax regime for agricultural organizations

There are also restrictions on the transition to the simplified taxation system related to the type of economic activity of the organization.

The following criteria are established for the transition to the unified tax on imputed income:

- activity of the organization (part of the activities) is included in the list specified in para. 2 of Art. 346.46 of the Tax Code of the Russian Federation;

- the share of participation of other organizations must not exceed $25 \%$;

- the average annual number of employees must not exceed 100 people.

Figure 3 shows the algorithm for the analysis of eligibility for transition to special tax regimes for agricultural organizations.

It should be noted that there are other restrictions on the transfer to special tax regimes (for example, activities related to organization and conduct of gambling), however, these criteria are not typical for agricultural organizations so they were not included in the list of provisions that require analysis.
On the basis of this algorithm we have developed a form of a checklist for the assessment of compliance with the conditions of transition to special tax regimes, and conducted a test for compliance with the terms of application of special tax regimes using the example of Plemzavod Chapayev, OJSC (Table 1).

Thus, Plemzavod Chapayev, OJSC complies with the conditions of application of the unified agricultural tax. The specified organization has no right to transfer to the simplified taxation system due to non-compliance of its level of income, average staff number and depreciated book value of fixed assets with the criteria established by the Tax Code of the Russian Federation.

Also, Plemzavod Chapayev, OJSC has no areas of activity that could be subject to the unified tax on imputed income.

The next step is the analysis of the tax field for different tax schemes. The tax field for the standard taxation scheme, unified agricultural tax and simplified tax system is shown in Figure 4. Let us consider the advantages and disadvantages of UAT, which is the most common tax regime $(73.4 \%$ of taxpayers applied this tax regime in 2016).

In our opinion, the criterion of the proportion of income from the sale of agricultural products $(70 \%)$ is a significant obstacle to the transition to UAT for major agricultural organizations (they rarely meet this criterion, as they are often characterized by the diversification of activities). 
TABLE I.

THE CHECKLIST FOR THE ASSESSMENT OF COMPLIANCE WITH THE CONDITIONS OF TRANSITION TO SPECIAL TAX REGIMES FOR PLEMZAVOD CHAPAYEV, OJSC, 2016

\begin{tabular}{|c|c|c|c|c|}
\hline & Criterion & $\begin{array}{l}\text { Limit } \\
\text { value of } \\
\text { the } \\
\text { criterion }\end{array}$ & $\begin{array}{c}\text { Value of } \\
\text { the } \\
\text { parameter } \\
\text { for } \\
\text { Plemzavod } \\
\text { Chapayev, } \\
\text { OJSC }\end{array}$ & $\begin{array}{l}\text { Comp } \\
\text { liance } \\
\text { with } \\
\text { the } \\
\text { criteri } \\
\text { on }\end{array}$ \\
\hline & $\begin{array}{l}\text { Income multiplied by the } \\
\text { deflator coefficient, } \\
\text { million rubles }\end{array}$ & 52 & 75 & no \\
\hline & $\begin{array}{l}\text { Average annual number of } \\
\text { employees, pers. }\end{array}$ & 100 & 903 & no \\
\hline छี & $\begin{array}{l}\text { Share of other } \\
\text { organizations, } \%\end{array}$ & 25 & 10 & yes \\
\hline 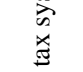 & $\begin{array}{l}\text { Depreciated book value of } \\
\text { fixed assets, million rubles }\end{array}$ & 100 & 566 & no \\
\hline$\overline{0}$ & Existence of branches & no & no & yes \\
\hline : & $\begin{array}{l}\text { Production of excisable } \\
\text { goods }\end{array}$ & no & no & yes \\
\hline & $\begin{array}{l}\text { Extraction of minerals, } \\
\text { except for commonly } \\
\text { occurring }\end{array}$ & no & no & yes \\
\hline & $\begin{array}{l}\text { State-owned or budgetary } \\
\text { institution }\end{array}$ & no & no & yes \\
\hline & Foreign organization & no & no & yes \\
\hline 己 & $\begin{array}{l}\text { The proportion of income } \\
\text { from the sale of } \\
\text { agricultural products in the } \\
\text { total amount of income, } \%\end{array}$ & 70 & 84 & yes \\
\hline 光 & $\begin{array}{l}\text { Production of excisable } \\
\text { goods }\end{array}$ & no & no & yes \\
\hline & $\begin{array}{l}\text { State-owned, budget, } \\
\text { autonomous institution }\end{array}$ & no & no & yes \\
\hline 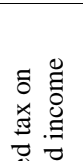 & $\begin{array}{l}\text { A part of activities of the } \\
\text { organization is an activity } \\
\text { specified in para. } 2 \text { of Art. } \\
346.46 \text { of the Tax Code of } \\
\text { the Russian Federation }\end{array}$ & yes & no & no \\
\hline 莺 & $\begin{array}{l}\text { Average number of } \\
\text { employees }\end{array}$ & 100 & no & no \\
\hline & $\begin{array}{l}\text { Share of other } \\
\text { organizations }\end{array}$ & 25 & yes & yes \\
\hline
\end{tabular}

Due to the fact that organizations with UAT are exempt from VAT, there is a high probability of loss of counterparties because of their inability to obtain the VAT offset. Whereas sales of most of the products by agricultural organizations with the standard taxation scheme are subject to VAT at the rate of $10 \%$, while VAT recoverable is often calculated based on the rate of $18 \%$, so in the end the taxpayer is exempt from VAT and entitled to receive compensation from the budget. In addition, according to subpara 1.3, para. 1 of Art. 284 of the Tax Code of the Russian Federation, the activities of agricultural producers that meet the criteria specified in para. 2 of Art. 346.2 of the Tax Code of the Russian Federation and activities related to the sales of agricultural products produced by the taxpayers are taxed at the rate of $0 \%$. Application of this provision may significantly reduce the tax burden on organizations with the standard taxation scheme. And the advantage of UAT, which is reduction of the tax burden by the amount of corporate income tax, applies only to organizations with a significant proportion of activities not related to sales of agricultural products produced by them.

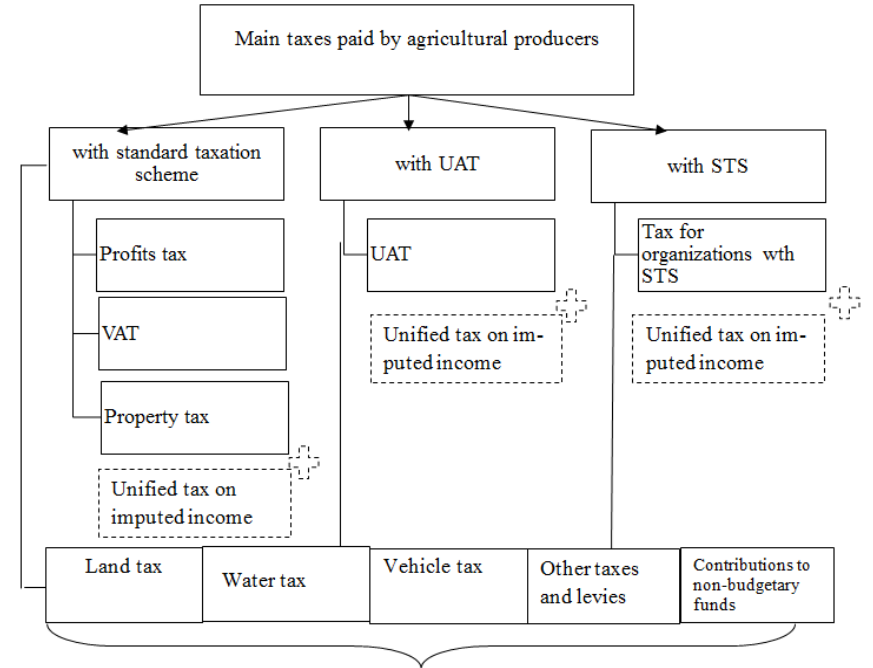

Fig.4 Tax field of agricultural organizations with standard and special taxation schemes

As for the transition to the simplified tax system, only small agricultural producers can apply this tax regime and that is a small proportion of agricultural organizations, which is confirmed by the statistical data presented in the second section of the paper.

After the analysis of eligibility for transition to special tax regimes and consideration of their advantages and disadvantages, calculation of tax burden is carried out.

The calculation of tax expense and tax burden should be implemented on the basis of planned targets for the next year as the application for transition to a special tax regime is submitted to the tax authorities not later than December 31 of the calendar year preceding the calendar year in which the organization is planning to transfer to a special tax regime. Thus, the selection of the optimal taxation scheme is one of the objectives of prospective tax analysis.

The estimated net tax expense for agricultural enterprises with the standard taxation scheme can be determined using the formula:

$$
\mathrm{TE}=\mathrm{T}_{\mathrm{i}}+\mathrm{VAT}+\mathrm{T}_{\mathrm{p}},
$$

where TE is the net tax expense, ths. rub.;

$\mathrm{T}_{\mathrm{i}}-$ income tax, ths. rub.;

VAT - the amount of value added tax to be paid for the year;

$\mathrm{T}_{\mathrm{p}}$ - the amount of property tax.

This figure is compared to the planned amount of the unified agricultural tax:

$$
\mathrm{UAT}=(\mathrm{I}-\mathrm{E}) \times 100 \%
$$

where UAT is the planned value of tax liability for the unified agricultural tax for the next year, ths. rub.; 
I - the amount of income adopted for the calculation of the unified agricultural tax, ths. rub.;

$\mathrm{E}$ - the amount of expense adopted for the calculation of the unified agricultural tax, ths. rub.;

Let us consider the procedure for calculation of the optimal taxation scheme using the example of Plemzavod Chapaev, OJSC located in Dinskaya district (Table 2). The organization is currently applying a special tax scheme (UAT). Since Plemzavod Chapaev, OJSC does not meet the criteria for transition to the STS, the table below shows the comparison of tax expenditures of the organization concerned with the application of the special tax regime for agricultural producers and the standard taxation scheme.

TABLE II. SELECTION OF THE OPTIMAL TAXATION SCHEME USING THE EXAMPLE OF PLEMZAVOD CHAPAEV, OJSC

\begin{tabular}{|l|c|c|}
\hline \multicolumn{1}{|c|}{ Parameter } & Taxation scheme \\
\cline { 2 - 3 } & $\begin{array}{c}\text { Standard } \\
\text { taxation } \\
\text { scheme }\end{array}$ & UAT \\
\hline $\begin{array}{l}\text { Tax base for calculation of income tax at the } \\
\text { rate of 20\%, ths. rub. }\end{array}$ & 5708 & $\times$ \\
\hline The amount of income tax, ths. rub. & 1142 & $\times$ \\
\hline Tax base for calculation of UAT, ths. rub. & $\times$ & 89750 \\
\hline The amount of UAT, ths. rub. & $\times$ & 5385 \\
\hline $\begin{array}{l}\text { The amount of VAT accrued on revenues, } \\
\text { ths. rub. }\end{array}$ & 89586 & $\times$ \\
\hline The amount of VAT deductible, ths. rub. & 86369 & $\times$ \\
\hline The amount of VAT payable, ths. rub. & 3217 & $\times$ \\
\hline $\begin{array}{l}\text { The amount of corporate property tax, ths. } \\
\text { rub. }\end{array}$ & 6818 & \\
\hline $\begin{array}{l}\text { The amount of other taxes, levies (exclusive } \\
\text { of personal income tax) and contributions to } \\
\text { non-budgetary funds, ths. rub. }\end{array}$ & & 81905 \\
\hline $\begin{array}{l}\text { Total amount of obligations for taxes, levies } \\
\text { (exclusive of personal income tax) and } \\
\text { contributions to non-budgetary funds, ths. } \\
\text { rub. }\end{array}$ & & 893082 \\
\hline Revenues (excluding VAT), ths. rub. & 895369 & 895369 \\
\hline Tax burden on revenue, $\%$ & 10,4 & 9,7 \\
\hline
\end{tabular}

We can see from the Table 2 that in case of applying standard taxation scheme tax expenditures would have amounted to 93,082 ths. rub., which is 5,729 ths. rub. more than in case of applying the unified agricultural tax. In case of transition to standard taxation scheme the tax burden would increase by 0.7 percentage points. Therefore, it is advisable for Plemzavod Chapaev, OJSC to continue using the special tax regime for agricultural producers.

\section{CONCLUSION}

The choice of the optimal taxation scheme is extremely important for the effective management of the tax costs of agricultural organizations in the Krasnodar Territory. The correct choice of the taxation scheme will allow to significantly minimize the tax burden of the economic entity. It is necessary to analyze eligibility for transition to a particular tax regime, consider the tax field for each taxation scheme, and calculate the planned tax expenditures and tax burden for each alternative prior to the adoption of management decision.

\section{Acknowledgment}

The study was carried out with the financial support of the RFBR and the administration of the Krasnodar Territory within the framework of the scientific project No. 16-46230131

\section{References}

[1] Artanova, L.I. Peculiarities of the formation of the tax burden under different taxation regimes / L.I. Artanova // National and international financial and economic problems of road transport Collected scientific works. - Moscow, 2017. - P. 111-114.

[2] Vasiliev, A.M. Tax analysis in the system of forecasting and planning of taxation at the micro level: dis. ... doc. econ. Sci. / A.M. Vasiliev. - The eagle. - 2012. - 182 p.

[3] Vylkova, E.S. Tax planning. Theory and practice: a textbook for universities / E.S. Vylkova. - 2 nd ed. Pererab. and additional. Moscow: YURAYT, 2014. - 672 p.

[4] Evstegneev, E.N. Tax management and tax planning in Russia: Monograph / E. N. Evstegneev, N. G. Viktorova. - M .: SRC Infra-M, 2012. - 270 p.

[5] Kirina, A.S. Tax management in organizations: textbook / A.S. Kirina, N.A. Gorokhov. - Moscow: YURAYT, 2014. - 288 p.

[6] Lyukmanov, K.M. Information-analytical component of the formation of taxable indicators at the enterprise level / K.M. Lokmanov // Managerial Accounting. - 2013. - No. 8. - P. 85-93. 